\title{
Shear Strength Behavior for Unsoaked and Soaked Multistage Triaxial Drained Test
}

\author{
Abdul Samad AR*, NorbayaS, Juhaizad A, Hazwani Md Zain and IkmalFR \\ Faculty of Civil Engineering, UniversitiTeknologi MARA, Malaysia \\ *Corresponding author: Abdul Samad AR, Faculty of Civil Engineering, Malaysia
}

Submission: 䀺June 25, 2018; Published: 眥 July 09, 2018

\begin{abstract}
To determine the mode of slope failures is very difficult especially when using the conventional slope stability method which applies the linear type of strength variation with respect to effective stress and suction. These studies conducted to fulfil the real failure mechanism of slope failure which acquired the analysis of shear strength behaviour incorporatecurve-linear relative to effective stress and non-linear relative to suction. Three undisturbed samples were collected at Precinct 9, Putrajaya at different depth to determine the multistage triaxial drained test with unsoaked, soaked for 7 days and soaked for 14 days sample.Finding shows that from the test, there are a slightly reduction in shear strength between all the samples. For unsoaked sample, the shear strength was $28^{\circ}$, soaked for 7 days was $25^{\circ}$ and soaked for 14 days was $22^{\circ}$. The shear strength parameters obtain from the results will used in slope stability analysis in order to define the Factor of Safety for the slope failure.
\end{abstract}

Keywords:Multistage; Shear strength;Unsoaked; Soaked

\section{Introduction}

Malaysia is located in a semi-arid region which has hot and humid climate all year long. The pattern of slope failure that occurred normally of shallow types and the groundwater table were usually very deep and had no effect on the failure. This is a common type of failure in tropical countries which received high annual rainfall. The term "shallow" here is referring to the movement of the soil above the toe which moves downwards without under cutting the toe. Slope failure of shallow type is confined within unsaturated zone when it is infiltrated by the surface water. It is very important to understand the mode of failure triggered by rain water infiltration. Despite the soil condition during failure is unsaturated; the shear strength applied in a slope stability analysis is always the saturated shear strength since in the conventional triaxial test the specimen was already being saturated prior to shearing

Hence, the understanding of mode of failure in natural or manmade slope is required in order to produce an appropriate slope stability equation where it is applicable to real case scenario of a slope failure. By understanding the actual mode of failure occurs in shallow type of landslide, it is hoped that the slope stability computational programme will be more reliable and reflective of the actual stability state. Furthermore, during the stage of design, most of the geotechnical engineers tend to design the slope stability based on empirical methods which require a high degree of engineering judgment which are derived from a lot of practical experiences.

\section{Literature Review}

Shear strength can be defined as the maximum value of shear stress that the soil can withstand. The shear strength of soils is controlled by effective stress, weather failure occurs under drained or undrained conditions [1]. The first ever shear strength equation that incorporates with a linear shear strength envelope with respect to effective stress was introduced by Terzaghi [2]. After that, Bishop et al. [3] extends the understanding of Terzaghi [2] equation by introduced the relationship between the degree of saturation, $\mathrm{S}_{\mathrm{r}}$ and the empirical parameter, $\chi$. The value of $\chi$ is assumed to vary from 1 to 0 , which represents the variation from a fully saturated condition to a total dry condition. These studies have indirectly provided an important milestone in understanding the relationship between shear strength and the soil-water characteristic curve behaviour. Barbour [4] where the stress that sustains by the skeleton is known as effective stress. The hydrostatic stress that exists from the water in the voids is known as pore water pressure.

In practice, geotechnical engineers always assume that the pore water pressure above the ground water table is negligible and in a positive value whereas in reality, the unsaturated soil which above the ground water table, the pore water pressure is in a negative value. Pour water pressure of negative values with respect to the atmospheric pressure contributes to a higher effective stress and thus in a higher shear strength [5]. Furthermore, for an effective stress analysis, a soil is assumed to be in a drained condition 
whereas the changes in load are slow enough that the load induces no excess pore water pressure and the water can slowly dissipate from soil. Therefore, to perform effective stress analysis, it is necessary to subtract the pore water pressure from the total stress [1].

The first equation that incorporates the two independent stress state variables which net stress $\left(\sigma-u_{a}\right)$ and suction $\left(u_{a}-u_{w}\right)$ are commonly used to describe the behaviour of unsaturated soil is proposed as a planar surface in $\tau:\left(\sigma-u_{a}\right):\left(u_{a}-u_{w}\right)$ space, which refers to extended Mohr Coulomb space [6].

Referring to Figure 1, the figure shows the failure envelope drawn tangent to the Mohr circle. The shear strength of unsaturated soil is drawn based on the extended Mohr Coulomb failure envelope.

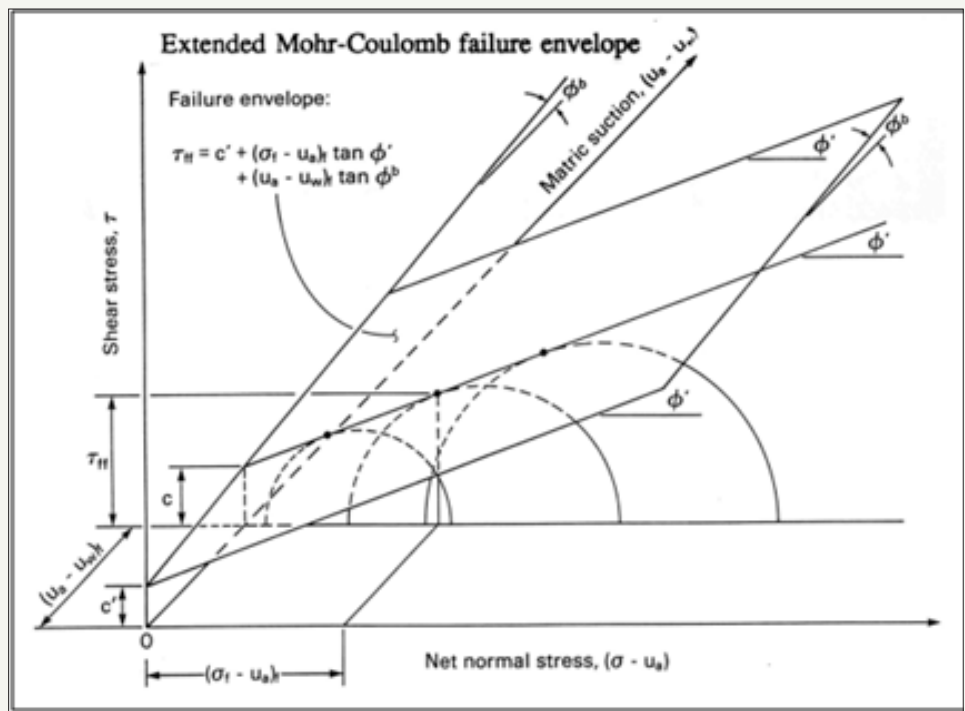

Figure 1: Shear strength model ofFredlund et al. [6].

$\tau_{f}=c^{\prime}+\left(\sigma_{n}-u_{a}\right) \tan \phi^{\prime}+\left(u_{a}-u_{w}\right) \tan ^{b}$

Where,

$\sigma_{\mathrm{n}}=$ total normal stress

$\mathrm{u}_{\mathrm{a}}=$ pore-air pressure

$\mathrm{u}_{\mathrm{w}}=$ pore-water pressure

$\varphi^{\mathrm{b}}=$ rate of increase in shear strength with matric suction or unsaturated friction angle

The shear strength of an unsaturated soil is considered to consist of an effective cohesion, $c^{\prime}$ and the independent contributions of net normal stress, $\left(\sigma-u_{a}\right)$ and the matric suction, $\left(u_{a}-u_{w}\right)$. The shear strength contributed from net normal stress and matric suction are characterized by $\varphi^{\prime}$ and $\varphi^{\mathrm{b}}$ angles respectively. The equation of this shear strength for unsaturated soil condition is considered linear with respect to effective or net stress whereas recent experimental evidence established by Donald [7], Escario \& Saez [8] and Fredlund [9]; suggest that there can be a significant non-linearity in the shape of failure envelope with respect to matric suction. Figure 2 shows the non-linear behaviour of shear strength with respect to suction which done by Gan \& Fredlund [10]. The figure shows the experimental evidence of the non-linear behaviour due to suction in different value of matric suction.

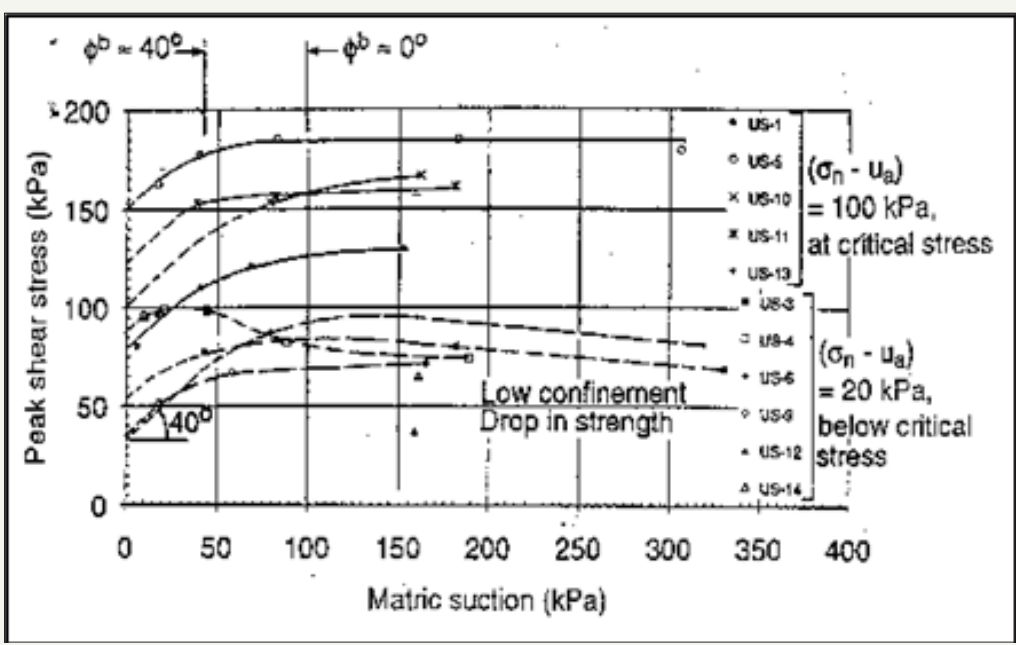

Figure 2: Non-linear behaviour of shear strength with suctionGan \&Fredlund [10]. 
Bishop [11] conducted shear strength test for different soil properties shown in Figure 3. The testing was carried out for two different soil categories namely granular and cohesive soils. All the result shows that the shear strength was intercept at zero in shear stress-effective stress plane.

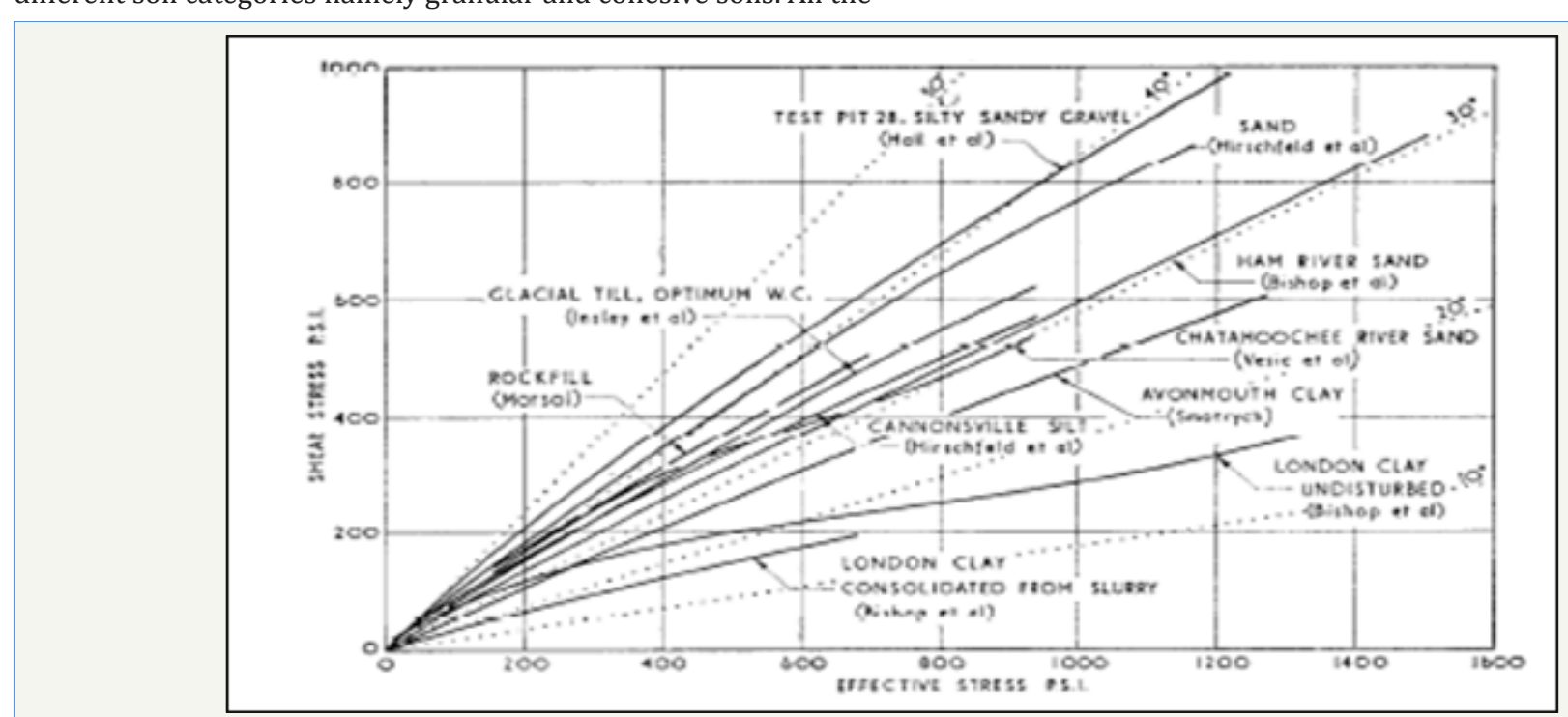

Figure 3: Non-linear shear strength behaviour with respect to effective stress [11].

Furthermore, substantial amount of experimental evidence suggest that the failure criteria of many soils are non-linear, particularly in a range of small normal stresses $[12,13]$. This finding of non-linearity in Mohr Coulomb failure envelope is significant for slope stability calculation since for a wide range of practical stability problems, critical slip surface is shallow and normal stresses acting on such surfaces are small. A comprehensive approach to a slope stability calculation which integrates experimental and computational aspects of the problem, shows that non-linearity of failure criterion may have a very significant effect on slope design [14].

\section{Research Methodology}

The determination of engineering properties will base on finding the effective cohesion, $c^{\prime}$ and effective internal friction angle, $f^{\prime}$ of the samples. Therefore, to determine this parameter, triaxial testing will be carried out. Triaxial testing is the common method that uses to determine the shear strength of the soil. Among the advantages of using this triaxial is that the shear failure plane is not predetermine but the shear failure plane will occur at the weakest spot of the sample. Besides that, the excessive of pore water pressure can be controlled, monitored and measured. In addition, with these aids of excessive pore water pressure, the sample can be strengthening first by means of consolidated the specimen. During this stage, the axial load will load slowly enough so that no access of pore water pressure is induced by applied loads. The relation on the field is when in drained condition result when loads are applied slowly to a mass of soil, or where they persist for a long enough time so that the soil can drain. In the laboratory, drained conditions are achieved by loading the sample slowly so that excess pore pressure do not develop as the soil is loaded. The shear strength parameters gathered are the effective internal friction angle, $\varphi^{\prime}$, transition shear strength, $\tau_{t}$ and transition effective stress, $\left(\sigma-u_{w}\right)_{t}$ according to the curved-surface envelope shear strength model. The shear strength properties will be interpreted based on the curved-surface envelope shear strength model of Md. Noor \& Anderson [15] and linear envelope of Terzaghi [2] and Fredlund et al. [6].

In addition, multi-stage consolidated drained triaxial was decided in order to avoid the problem of variability between samples. When this has been avoided it will ease the interpretation of the shear strength envelope. This testing technique is very important when the effect of soaking on the reduction of shear strength is to be incorporated in the analysis. Variability between the samples will cause the complexity in the interpretation of strength envelope itself and further complexity when the effect of soaking is to be incorporated. The shearing for the multi-stage test is terminated when failure is imminent. About 3 samples in different condition of test will be carried out. For unsoaked condition, the sample was tested in normal ways of triaxial testing which being consolidated in the first place and water allow to flow through the sample prior to shearing stages while for soaking condition weather for 7 or 14 days, the sample was soaked first before it can be consolidated and shear. The soaking process can be achieved in cell bodies by allowing back pressure and cell pressure flowing through which a value of $50 \mathrm{kPa}$ will be applied to the cell pressure and $45 \mathrm{kPa}$ will be applied to back pressure. Thus, the different of $5 \mathrm{kPa}$ will be the soaking value of the sample allowing through for the desired time. Sample will be under soaking process for the desired time where all the microstructures of the sample are being saturated.

Table 1 shows the tabulation of multistage consolidated drained test in Precinct 9, Putrajaya. There are about 3 conditions of samples which is unsoaked, soaked for 7 and 14 days were tested. These undisturbed samples were tested at different of effective stress ranging from 50 to $300 \mathrm{kPa}$ while Figure 4 shows the layout location of Borehole 1 and Borehole 2 in Precinct 9, Putrajaya. 
About 3 undisturbed samples were used for the test at different depth where for unsaturated condition; the samples were taken at the depth of $1.5 \mathrm{~m}$ from BH1. On the other hand, samples that used

Table 1: Tabulation of multistage consolidated drained test in Precinct 9, Putrajaya.

\begin{tabular}{|c|c|c|c|c|c|c|c|}
\hline \multirow[t]{3}{*}{ Location } & \multirow{2}{*}{ Borehole No. } & \multirow{2}{*}{$\begin{array}{c}\text { Depth } \\
\text { (m) }\end{array}$} & \multirow{2}{*}{ Condition of Samples } & \multicolumn{4}{|c|}{ Effective Stress (kPa) } \\
\hline & & & & \multicolumn{4}{|c|}{ CD Triaxial Test } \\
\hline & BH1 & 1.5 & Unsoaked & 50 & 100 & 200 & 300 \\
\hline \multirow{2}{*}{$\begin{array}{c}\text { Precinct } \\
9\end{array}$} & \multirow{2}{*}{$\mathrm{BH} 2$} & 4 & Soaked for 7 days & 50 & - & 200 & 300 \\
\hline & & 5 & Soaked for 14 days & 50 & 100 & 200 & 300 \\
\hline
\end{tabular}

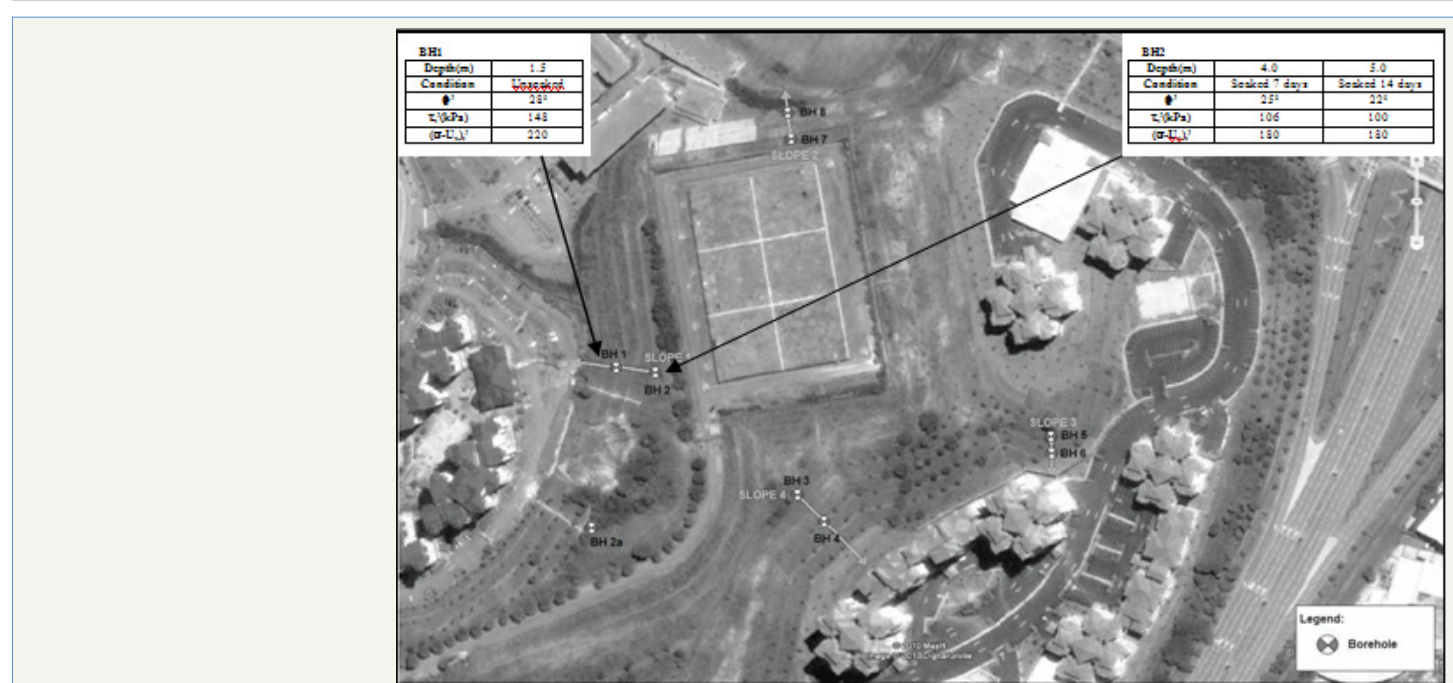

Figure 4: Layout location of borehole for Precinct 9, Putrajaya.

\section{Result and Analysis}

Table 2 shows the tabulation of effective shear strength parameters incorporates curvi-linear shear strength envelope for Precinct 9, Putrajaya. Finding shows that there are slightly decreasing in shear strength between unsoaked and soaking samples. For unsoaked sample, the effective internal friction angle, for the soaked test in 7 and 14 days were collected at the depth of 4 and $5 \mathrm{~m}$ consecutively from $\mathrm{BH} 2$.

Table 2: Tabulation of effective shear strength parameters incorporates curvi-linear shear strength envelope for Precinct9, Putrajaya.

\begin{tabular}{|c|c|c|c|c|c|c|c|c|c|}
\hline \multirow[b]{2}{*}{ Location } & \multirow{2}{*}{$\begin{array}{c}\text { Borehole } \\
\text { No. }\end{array}$} & \multirow[b]{2}{*}{$\operatorname{Depth}(\mathrm{m})$} & \multirow{2}{*}{$\begin{array}{c}\text { Effective Stress, } \\
\text { kPa }\end{array}$} & \multicolumn{3}{|c|}{ Condition of Failure } & \multicolumn{3}{|c|}{ Shear Strength Parameters } \\
\hline & & & & $\begin{array}{c}\text { DS } \\
(\mathrm{kPa})\end{array}$ & $\begin{array}{l}\text { PWP } \\
\text { (kPa) }\end{array}$ & $\begin{array}{c}\mathrm{CP} \\
(\mathrm{kPa})\end{array}$ & $\varphi^{\prime}$ & $\begin{array}{r}t_{t} \\
k \mathrm{Paa}\end{array}$ & $\begin{array}{c}\left(\sigma-U_{w}\right)_{t} \\
k P a\end{array}$ \\
\hline \multirow{11}{*}{ Precinct } & \multirow{4}{*}{$\begin{array}{c}\text { BH1 } \\
\text { Unsoaked }\end{array}$} & \multirow{4}{*}{1.5} & 50 & 161 & 386 & 450 & \multirow{4}{*}{$28^{\circ}$} & \multirow{4}{*}{148} & \multirow{4}{*}{220} \\
\hline & & & 100 & 266 & 386 & 498 & & & \\
\hline & & & 200 & 416 & 385 & 595 & & & \\
\hline & & & 300 & 565 & 385 & 695 & & & \\
\hline & \multirow{7}{*}{$\begin{array}{l}\text { BH2 } \\
\text { Soaked }\end{array}$} & \multirow{3}{*}{$\begin{array}{c}4.0 \\
\text { (7 days) }\end{array}$} & 50 & 134 & 483 & 544 & \multirow{3}{*}{$25^{\circ}$} & \multirow{3}{*}{106} & \multirow{3}{*}{180} \\
\hline & & & 200 & 220 & 496 & 690 & & & \\
\hline & & & 300 & 472 & 512 & 789 & & & \\
\hline & & \multirow{4}{*}{$\begin{array}{c}5.0 \\
\text { (14 days) }\end{array}$} & 50 & 165 & 437 & 494 & \multirow{4}{*}{$22^{\circ}$} & \multirow{4}{*}{100} & \multirow{4}{*}{180} \\
\hline & & & 100 & 229 & 437 & 546 & & & \\
\hline & & & 200 & 311 & 437 & 646 & & & \\
\hline & & & 300 & 444 & 437 & 746 & & & \\
\hline
\end{tabular}




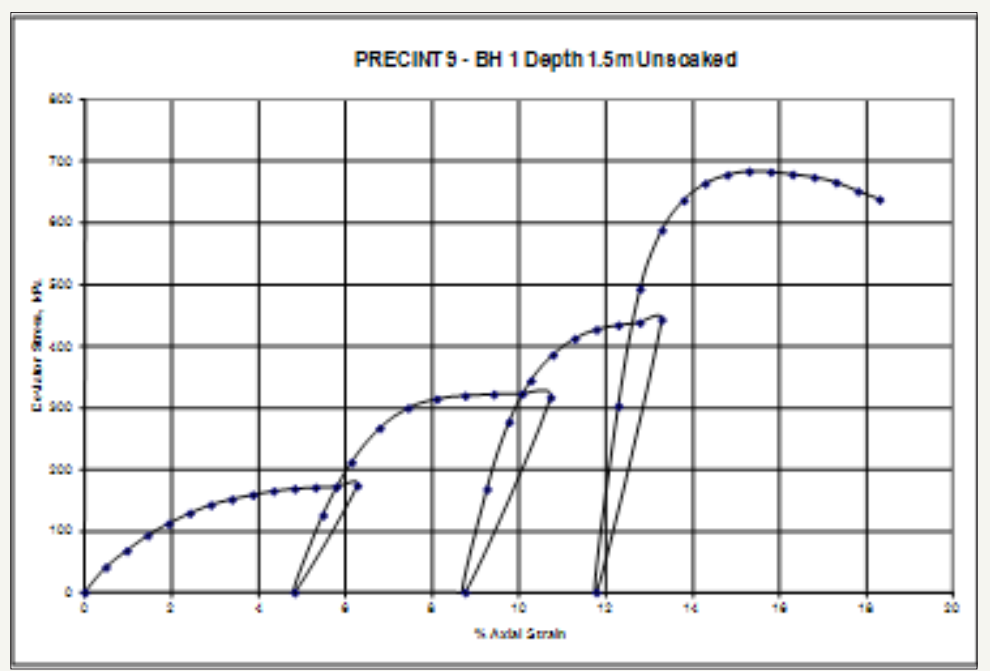

Figure 5: Multistage stress-strain for unsoakedsample depth of $1.5 \mathrm{~m}$ in Precinct 9, Putrajaya.

In order to determine the effective internal friction angle, $\varphi^{\prime}$ of the sample, stress-strain plain needs to be plotted using data in multistage triaxial testing. The maximum stress of the sample when failure will be recorded in each stage of effective stress as shows in Figure 5.

Figure 6 shows the combination of failure envelope for each sample in different condition when using curvi-linear shear strength envelope. It found that the shear strength was reduced when soaked into the water for 7 and 14 days consecutively compared to unsoaked sample. The reduction of shear strength between soaked 7 and 14 days were at $3^{\circ}$ while for unsoaked compare to soaked for 14 days were about $6^{\circ}$. Finding shows that during soaking period, the micro structures of the soil is getting weaker due to existence of water. Upon that, if the soil is being wetted for a longer time, the shear strength of the soil will keep decreasing.

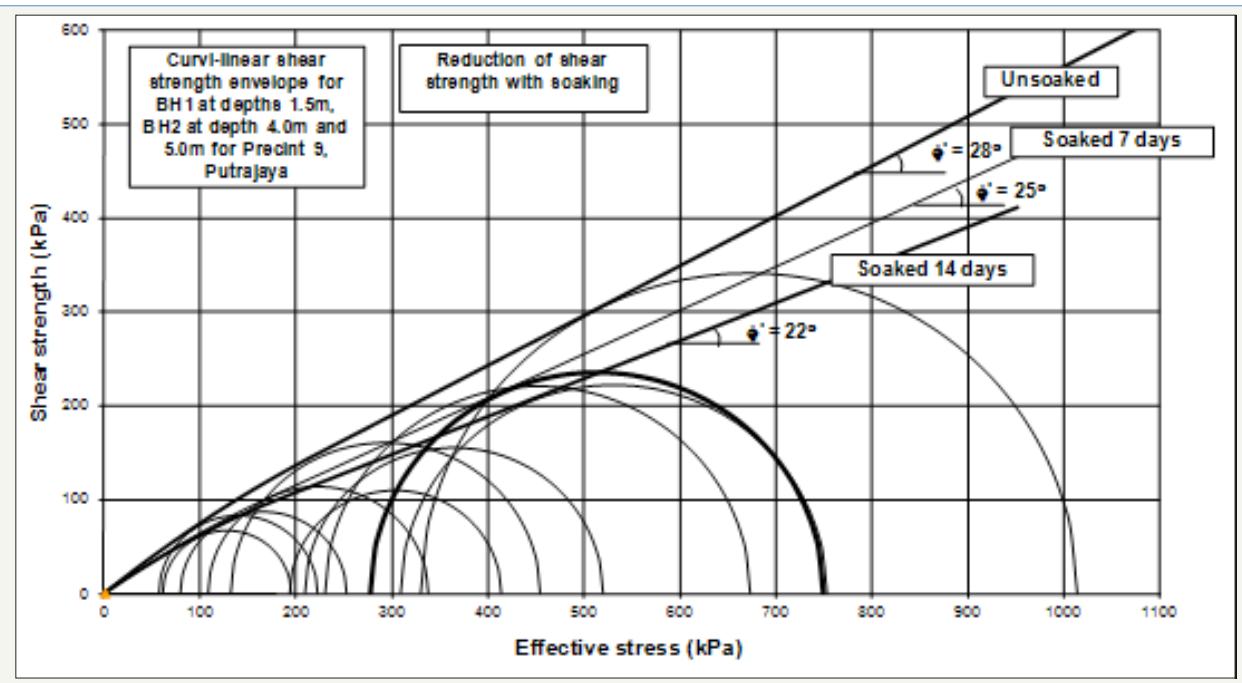

Figure 6: Combination failure envelope using curvi-linear shear strength envelope for unsoaked, soaked for7 days and soaked for 14 days.

\section{Conclusion}

There is a significant reduction between unsoaked and soaked samples with respect to effective friction angle, $\varphi^{\prime}$ of the shear strength of the soil. If the soil is been soaked into water, the shear strength will be decreasing tremendously and it will further decrease with time when the soil is too long soaked into water. These can be found from the results where there is substantial different amount of effective friction angle by $6^{\circ}$ when compare to unsoaked and soaked sample for 14 days. Furthermore, there is also a reduction in effective friction angle by $3^{\circ}$ between unsoaked and soaked sample for 7 days. Soaking sample in the triaxial involved complex processes and it is a kindly new approached to monitor the effect of shear strength of soil due to soaking effect. Findings have proven that shear strength in soil will decline when the soil is soaked with water and will keep declining with time especially when it involved with clayey soil. Slope failure are normally associated with the rise of ground water table but in this research found that the most reasonable reason why slope failure is because of soil is being soaked into water for too long by water infiltration from rainfall intensity.

As a recommendation, in order to obtain more accurate results and interpretation of the shear strength of the soil, a longer soaking 
period might be the best option since previous results shows that shear strength of soil is keep decreasing with time if the sample is being soaking for too long.

\section{References}

1. Duncan JM, Wright SG (2005) Soil strength and slope stability. Canada: John Wiley \& Sons, New Jersey, USA.

2. Terzaghi KV (1936) Stability of slopes of natural clay. Proceedings of The First International Conference on Soil Mechanics and Foundation Engineering, Cambridge, England 1: 161-165.

3. Bishop AW, Alpan I, Blight GE, Donald IB (1960) Factor controlling the shear strength of partly saturated cohesive soils. Proceedings of The American Society of Civil Engineers Research Conference on Shear Strength of Cohesive Soils, Boulder, Colorado, USA, pp. 505-532.

4. Barbour SL (1999) The soil-water characteristic curve: a historical perspective. Nineteenth Canadian Geotechnical Colloquium, Canadian Geotechnical Journal 35(5): 873-894.

5. Md Noor MJ (2002) Arevised slope stability method to simulate shallow slope failures in tropical residual soil. $2^{\text {nd }}$ World Engineering Congress Sarawak, Malaysia.

6. Fredlund DG, Morgenstern NR, Widger RA (1978) The Shear strength of unsaturated soils. Canadian Geotechnical Journal 15(3): 313-321.

7. Donald IB (1956) Shear Strength measurements in unsaturated noncohesive soils with negative pore pressures. Proceedings of $2^{\text {nd }}$ AustraliaNew Zealand Conference of Soil Mechanic and Foundation Engineering, Christchurch, New Zealand, pp. 200-205.
8. Escario V, Saez, J (1986) The shear strength of partly saturated soils. Geotechnique 36(3): 453-456.

9. Fredlund DG (1987) Slope stability analysis incorporating the effect of soil suction. In: Anderson MG, Richards KS (Eds.), Chapter 4 in Slope Stability, New York: Wiley, USA, pp. 113-144.

10.Gan JKM, Fredlund DG (1996) Shearstrength characteristic of two saprolitic soils. Canadian Geotechnical Journal 33: 595-609.

11. Bishop AW (1966) The strength of soils as engineering materials. Geotechnique 16(2): 91-130.

12. Penman A (1953) Nonlinear failure envelope for soils. J Geotech Eng 115(4): 581-586.

13. Day RW, Axten GW (1989) Surficial stability of compacted clay slopes. J Geotech Eng 115(4): 577-580.

14. Baker R (2003) Inter-relations between experimental and computational aspects of slope stability analysis. International Journal Numerical Analysis Mathematically and Geomechanic 27(5): 34-42.

15. Md Noor MJ, Anderson WF (2006) Acomprehensive shear strength model for unsaturated soils. Proc of the $4^{\text {th }}$ Int Conference on Unsaturated Soils, Arizona, USA, 2: 1992-2003.

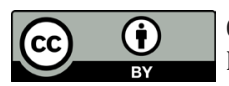

Creative Commons Attribution 4.0

International License

For possible submissions Click Here
Submit Article

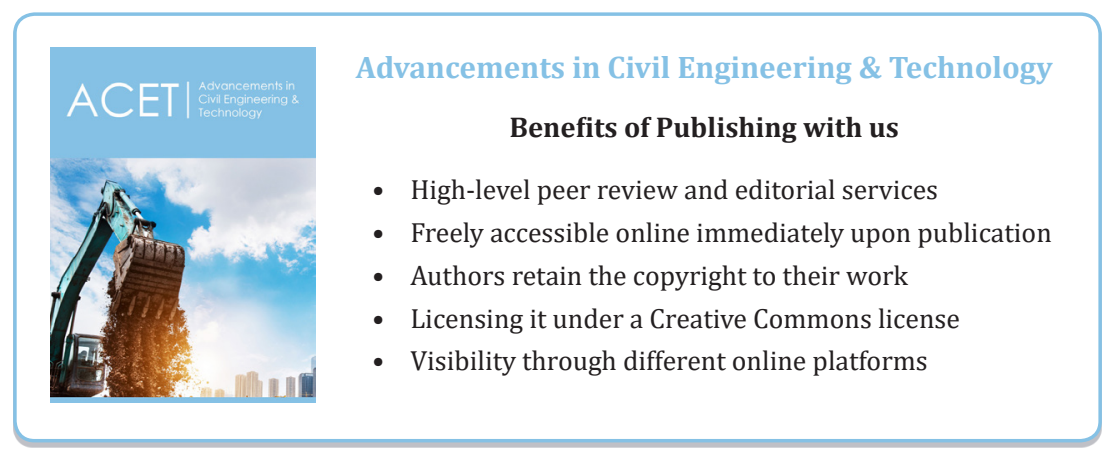

